\title{
Effects of inorganic and organic nutrient inputs on bacterioplankton community composition along a latitudinal transect in the Atlantic Ocean
}

\author{
Eva Teira $^{1, *}$, Sandra Martínez-García ${ }^{1}$, Alejandra Calvo-Díaz ${ }^{2,3,4}$, \\ Xosé Anxelu G. Morán ${ }^{2}$ \\ ${ }^{1}$ Departamento Ecología y Biología Animal, Facultad de Ciencias, Universidad de Vigo, Campus Lagoas-Marcosende, \\ 36310 Vigo, Spain \\ ${ }^{2}$ Instituto Español de Oceanografía, Centro Oceanográfico de Xixón, Camín de L'Arbeyal s/n, 33212 Xixón, Spain \\ ${ }^{3}$ Present address: Department of Biological Oceanography, Royal Netherlands Institute for Sea Research (NIOZ), PO Box 59, \\ 1790 AB Den Burg, The Netherlands \\ ${ }^{4}$ Present address: Department of Marine Biology, University of Vienna, Althanstrasse 14, 1090 Vienna, Austria
}

\begin{abstract}
Bacterioplankton are responsible for a large fraction of respiration and dissolved organic matter (DOM) remineralisation in the ocean; therefore, changes in their taxonomic composition due to changes in nutrient inputs may have important biogeochemical implications. The impact of nutrient loading will depend on the type of input and the initial environmental conditions. We conducted a set of 5 microcosm experiments along a broad latitudinal transect in the Atlantic Ocean $\left(26^{\circ} \mathrm{N}\right.$ to $\left.29^{\circ} \mathrm{S}\right)$ in order to assess the effects of inorganic (nitrate, ammonium, phosphate, silica) and organic (glucose, amino acids) inputs, added separately as well as jointly, on the bacterioplankton community composition at the level of major groups. We followed changes in the relative abundance of important bacterial phylogenetic (Roseobacter spp., SAR11, Gammaproteobacteria, Bacteroidetes) and cytometric (low, high and very high nucleic acid content) groups. We observed that distinct groups responded differently to nutrient additions: SAR11 and Bacteroidetes responded negatively to organic and mixed additions, while Roseobacter spp. and Gammaproteobacteria responded positively. Only the group Roseobacter spp. responded positively to inorganic additions. The abundance of very high nucleic acid content bacteria was low in the control and the inorganic treatment; however, they reached very high numbers in the organic and mixed treatments. There was a clear increasing north to south gradient in the magnitude of response of Gammaproteobacteria to organic inputs (containing carbon and nitrogen), likely related to an increasing north to south gradient in phosphate concentration. The magnitude of response of Gammaproteobacteria explained $89 \%$ of the observed variability in the magnitude of bacterial production response, which suggests a strong link between bacterial community composition and carbon cycling in the oligotrophic ocean.
\end{abstract}

KEY WORDS: Nutrient enrichment $\cdot$ Microcosms $\cdot$ Bacterioplankton $\cdot$ Oligotrophic ocean

\section{INTRODUCTION}

A predictable consequence of changes in land use and hydrologic and global biogeochemical cycles is the modification of the amount and nature of continental and atmospheric matter inputs into the world's oceans (Duce et al. 2008), which in turn will likely affect microbial plankton structure and functioning. Water-soluble organic nitrogen $(\mathrm{N})$ constitutes approximately 30 to $35 \%$ of total $\mathrm{N}$ atmospheric deposition (Cornell et al. 2003, Mace et al. 2003) with an important fraction likely being anthropogenic (Jickells 2006). Seitzinger \& Sanders (1999) found that a significant fraction of the atmospheric organic $\mathrm{N}$ is bioavail- 
able, and that 45 to $75 \%$ of the organic $\mathrm{N}$ in rainwater is rapidly utilised by microorganisms.

It has been suggested that in subtropical/tropical oceanic areas, characterised by low mixed-layer macronutrient concentrations, atmospheric inputs (including dry and wet deposition) may become a significant source of nutrients in ocean surface waters, compared to other oceanic areas (Baker et al. 2007).

Heterotrophic bacteria seem to be co-limited by $\mathrm{N}$ and phosphorus (P) in the oligotrophic subtropical North Atlantic (Mills et al. 2008) where additions of labile dissolved organic carbon (DOC) (glucose) alone do not stimulate bacterial activity or abundance. By contrast, many other studies found that bacteria are commonly limited or co-limited by carbon (C) in oligotrophic areas (Church et al. 2000, Carlson et al. 2002, Alonso-Sáez et al. 2007, Van Wambeke et al. 2008). Most nutrient-addition experiments use glucose as the labile organic $\mathrm{C}$ source. It has been demonstrated that glucose is not taken up equally by different bacterial groups (Alonso \& Pernthaler 2006, Alonso-Sáez \& Gasol 2007), which may imply contrasting responses to such $\mathrm{C}$ addition as a function of the initial bacterial community composition. Several nutrient-manipulation experiments have also addressed the response of bacteria to organic amendments using $\mathrm{N}$ compounds (glutamate, leucine, amino acids mixture) (Kirchman 1990, Carlson \& Ducklow 1996, Hasegawa et al. 2005, Davidson et al. 2007, Alonso-Sáez et al. 2009). Frette et al. (2004) found that $95 \%$ of the isolates, from 1 freshwater and 3 marine locations, were able to utilise dissolved free amino acids and protein as their sole $\mathrm{N}$ source. Microautoradiography studies combined with fluorescence in situ hybridisation (FISH) or catalysed reporter deposition-fluorescence in situ hybridisation (CARD-FISH) techniques have confirmed that most bacterial groups are able to use amino acids (Malmstrom et al. 2005, Alonso-Sáez \& Gasol 2007, AlonsoSáez et al. 2008), although the patterns of utilisation also greatly vary among bacterial groups.

Several studies have assessed changes in bacterial community structure after nutrient additions (Schäfer et al. 2001, Carlson et al. 2002, Sipura et al. 2005, Pinhassi et al. 2006, Allers et al. 2007, Davidson et al. 2007). However, the use of different experimental approaches (mesocosms, dilution cultures), together with the different quality and quantity of the enrichments and the different tools used for the characterisation of the bacterial community composition (FISH, fingerprinting techniques), make it difficult to directly compare the bacterial responses.

The impact of nutrient loading likely depends on the type of input, the initial environmental conditions, and the associated initial bacterial community. The higher rates of $\mathrm{N}$ fixation (Baker et al. 2007, Mather et al.
2008) and atmospheric deposition (Galloway et al. 2004) reported in the North than in the South Atlantic ocean suggest a potentially more severe $\mathrm{N}$ limitation in the South compared to the North Atlantic. A latitudinal gradient in phosphate concentration has been also reported by Mather et al. (2008) in the Atlantic Ocean. Changes in bacterial community composition have also been described along a latitudinal transect in the Atlantic Ocean (Schattenhofer et al. 2009).

We conducted a set of 5 enrichment microcosms experiments along a broad latitudinal transect in the Atlantic Ocean $\left(26^{\circ} \mathrm{N}\right.$ to $29^{\circ} \mathrm{S}$ ) (Fig. 1) in order to assess the response of different groups of heterotrophic bacteria to inorganic and/or organic nutrient inputs. Specifically, we wanted to test if the responses of the different bacterial groups were related to the initial bacterial community composition and/or nutrient status, and if changes in bacterial community composition were related to changes in bulk bacterial activity. We followed changes in the bacterial community composition at the level of major groups using CARD-FISH to detect 4 relevant bacterial groups (Roseobacter spp., SAR11, Bacteroidetes and Gammaproteobacteria), and flow cytometry to detect groups of bacteria with differing relative nucleic acid content. Changes in bulk bacterial production are discussed in detail in a companion paper (Martínez-García et al. 2010)

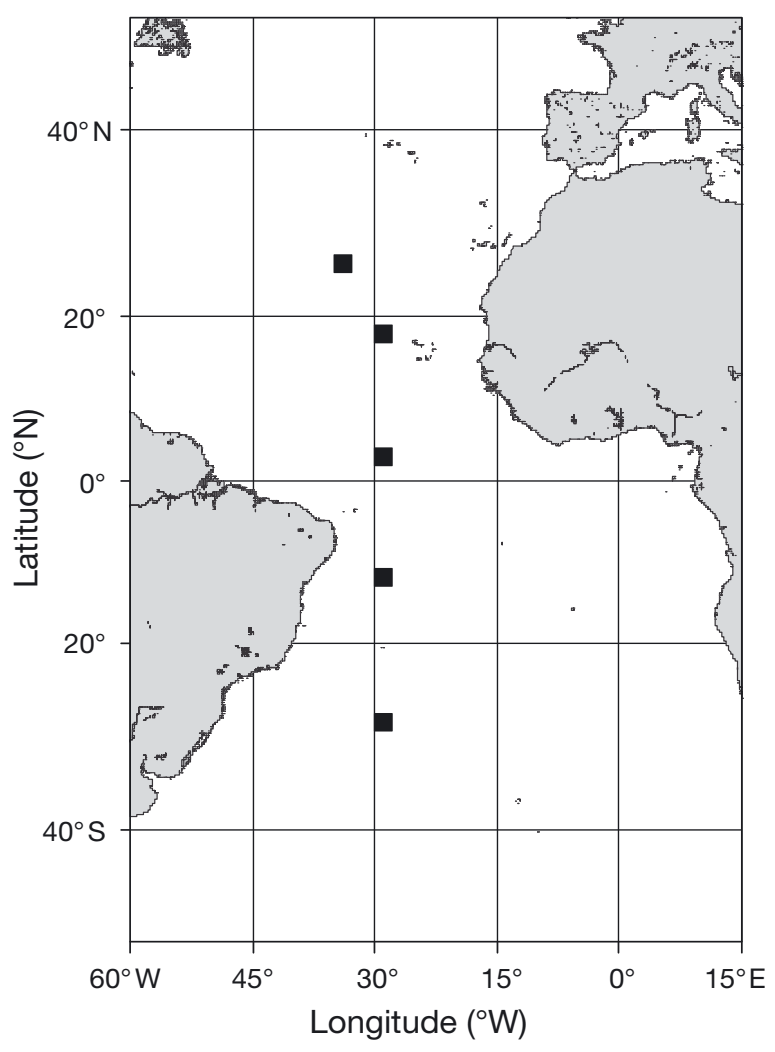

Fig. 1. Map of sampling stations (November 2007) 


\section{MATERIALS AND METHODS}

Experiments. We simulated increases in nutrient fluxes to surface waters (10 to $15 \mathrm{~m}$ depth) by means of a series of addition treatments using eight 121 polycarbonate carboys. Seawater was collected using 15 l acid-clean Niskin bottles attached to a rosette equipped with a CTD. The water was gently pre-filtered through a $150 \mu \mathrm{m}$ net to exclude big predators in order to ensure a good replication. Two microcosms were used as controls (no addition) and the other 6 were treated as follows: 2 were spiked with inorganic nutrients $(0.5 \mu \mathrm{M}$ nitrate, $0.5 \mu \mathrm{M}$ ammonium, $0.05 \mu \mathrm{M}$ phosphate and $0.1 \mu \mathrm{M}$ silicate), 2 with organic nutrients (0.5 $\mu \mathrm{M}$ glucose and $0.5 \mu \mathrm{M}$ amino acids), and 2 with both inorganic and organic nutrients (mixed treatment). These concentrations and proportions (N:Si:P, 20-30:2:1) were chosen based on an extensive review of the published data on the composition of atmospheric inputs to the Atlantic Ocean, including both dry and wet deposition (Baker et al. 2003, 2006, 2007, Duce et al. 2008). We decided not to add iron as we lacked the adequate equipment to manipulate large water volumes under trace metal-clean conditions. In addition, it has been found that $\mathrm{N}$ and $\mathrm{P}$ are the proximal limiting nutrients in the oligotrophic Atlantic Ocean (Mills et al. 2004, 2008, Moore et al. 2008). Organic N additions were performed to simulate previously reported increases in atmospheric bioavailable watersoluble organic N inputs (Seitzinger \& Sanders 1999, Mace et al. 2003, Duce et al. 2008). Although the amino acids provide both $\mathrm{C}$ and $\mathrm{N}$, glucose was also included since atmospheric depositions have been shown to contain not only nitrogenous organic compounds (Jurado et al. 2008, Pulido-Villena et al. 2008). PulidoVillena et al. (2008) reported an increase of DOC of ca. $3 \mu \mathrm{mol} \mathrm{C} \mathrm{l}^{-1}$ after a natural dust deposition event in the surface mixed layer of the Western Mediterranean. Therefore, our organic addition of ca. $5 \mu \mathrm{mol} \mathrm{C} \mathrm{l}^{-1}$ in the form of amino acids and glucose compares reasonably well with the observed increases in DOC.

To assess the short-term effects of the nutrient inputs, the microcosms were incubated during $72 \mathrm{~h}$ and samples were taken every $24 \mathrm{~h}$. Previous enrichment experiments have shown that a daily sampling frequency is adequate to describe the bacterioplankton response (e.g. Kirchman et al. 2000, Allers et al. 2007). The microcosms were maintained under simulated in situ irradiance (photoperiod and light intensity) and temperature in an indoor incubation chamber $\left(0.4 \mathrm{~m}^{3}\right)$ equipped with independent controls of photoperiod and temperature. Photosynthetically active radiation (PAR) within the incubation chamber, provided by 2 groups of 3 fluorescent lamps, ranged between 190 and $280 \mu \mathrm{E} \mathrm{m} \mathrm{m}^{-2} \mathrm{~s}^{-1}$, depending on the location of the carboy. The location of each carboy was randomly changed every day. We chose simulated and controlled conditions rather than in situ conditions in order to eliminate potential variability between experiments due to changes in local meteorological conditions (mainly light intensity) during the incubations. Time-zero sampling took place 1 to $2 \mathrm{~h}$ after nutrient addition. Time-averaged values were used to calculate the $\%$ of change in each treatment relative to control as follows: relative response $=[$ (mean value in treatment $\times 100) /$ mean value in control].

We followed changes in the relative abundance of important bacterial phylogenetic (Roseobacter spp., SAR11, Gammaproteobacteria, Bacteroidetes) and cytometric (low [LNA], high [HNA] and very high [vHNA] nucleic acid content) groups. In addition, concurrent measurements of bacterial production were done at each sampling point (Martínez-García et al. 2010).

Nutrients. The concentration of nitrate and ammonium was determined on-board on fresh samples with a Technicon segmented-flow auto-analyser and using modified colorimetric protocols that allowed the detection limit to be lowered to $2 \mathrm{nmol}^{-1}$ (Raimbault et al. 1990, Kerouel \& Aminot 1997). The concentration of phosphate was determined using standard procedures (Tréguer \& Le Corre 1975).

Chorophyll a (chl a) concentration. Chl a concentrations were measured in $250 \mathrm{ml}$ water samples that were filtered through $0.2 \mu \mathrm{m}$ polycarbonate filters. After extraction with $90 \%$ acetone at $4^{\circ} \mathrm{C}$ overnight at dark, chl a fluorescence was fluorimetrically determined.

Primary production. Four $75 \mathrm{ml}$ acid-cleaned bottles (3 light and 1 dark) were filled and inoculated with 7.5 to $20 \mu \mathrm{Ci} \mathrm{NaH}{ }^{14} \mathrm{CO}_{3}$. Samples were incubated for $12 \mathrm{~h}$ in the same incubation chamber as the microcosms (Martínez-García et al. 2010).

Bacterial heterotrophic production. The $\left[{ }^{3} \mathrm{H}\right] l e u c i n e$ incorporation method, modified as described by Smith \& Azam (1992), was used to determine bacterial production. Samples were incubated for 1.5 to $2 \mathrm{~h}$ in the same incubation chamber as the microcosms. Empirical leucine to $\mathrm{C}$ conversion factors (CF) were used calculate bacterial biomass production rates from Leu uptake rates (CF range: 0.17 to $0.21 \mathrm{~kg} \mathrm{C} \mathrm{mol} \mathrm{Leu}{ }^{-1}$ ).

In vivo electron transport system (ETS). ETS activity rate was used as an estimator of community respiration (CR). Size-fractionated in vivo ETS activity rates were measured as described by Martínez-García et al. (2009). Samples were incubated at the same temperature as the microcosm bottles and in dark conditions.

Bacterial community composition by CARD-FISH. Samples of 10 to $15 \mathrm{ml}$ were fixed with $0.2 \mu \mathrm{m}$ filtered paraformaldehyde (1\% final conc.) and subsequently stored at $4^{\circ} \mathrm{C}$ in the dark for 12 to $18 \mathrm{~h}$. Thereafter, each 
sample was filtered through a $0.2 \mu \mathrm{m}$ polycarbonate filter (Millipore, GTTP, $25 \mathrm{~mm}$ filter diam.) supported by a cellulose nitrate filter (Millipore, HAWP, $0.45 \mu \mathrm{m}$ ), washed twice with Milli-Q water, dried and stored in a microfuge vial at $-20^{\circ} \mathrm{C}$ until further processing in the laboratory.

The in situ abundance of different bacterial populations was determined using CARD-FISH with oligonucleotide probes specific for the domain Eubacteria (EUB338, EUB338II and EUB338III) (Amann et al. 1990, Daims et al. 1999), Gammaproteobacteria (GAM42a) (Manz et al. 1992) subclasses, the Bacteroidetes group (CF319a) (Manz et al. 1996), the Roseobacter spp. lineage (Ros537) (Eilers et al. 2001) and the SAR11 cluster (SAR11-441R) (Morris et al. 2002). Filters for CARDFISH were embedded in low-gelling-point agarose and incubated with lysozyme (Teira et al. 2008). Filters were cut in sections and hybridised at $35^{\circ} \mathrm{C}$ with horseradish peroxidase (HRP)-labelled oligonucleotide probes. Tyramide-Alexa488 was used for signal amplification (30 to $40 \mathrm{~min}$ ) as previously described (Pernthaler et al. 2002). We used $55 \%$ formamide for all probes except for SAR11-441R ( $45 \%$ formamide). The hybridisation for all the probes was done overnight and cells were counter-stained with a DAPI mix: 5.5 parts of Citifluor, 1 part of Vectashield (Vector Laboratories) and 0.5 parts of PBS with DAPI (final concentration $1 \mu \mathrm{g} \mathrm{ml}^{-1}$ ).

The slides were examined with an epifluorescence microscope equipped with a $100 \mathrm{~W}$ Hg-lamp and appropriate filter sets for DAPI and Alexa488. More than 800 DAPI-stained cells were counted per sample. For each microscope field, 2 different categories were enumerated: (1) total DAPI-stained cells and (2) cells stained with the specific probe. Negative control counts (hybridisation with HRP-Non338) averaged $0.25 \%$ and were always $<1.0 \%$ of DAPI-stained cells. The counting error, expressed as the percentage of standard error between replicates (SE/mean $\times 100$ ), was $<2 \%$ for DAPI counts and $<10 \%$ for FISH counts.

Flow cytometry. Samples for heterotrophic bacteria were preserved with $1 \%$ paraformaldehyde plus $0.05 \%$ glutaraldehyde and frozen at $-80^{\circ} \mathrm{C}$ until analysis with a FACSCalibur flow cytometer (Becton-Dickinson) equipped with a laser emitting at $488 \mathrm{~nm}$. After staining with SYBR-Green (see details in Calvo-Díaz \& Morán 2006), bacteria were separated into 3 groups based on their fluorescence and light scatter signals: LNA, HNA and vHNA bacteria. vHNA bacteria were characterised by much larger forward scatter and fluorescence (Fig. 2) than the HNA bacteria. For estimating the abundance of the different groups, calibration of the cytometer flow rate was performed daily. A solution of $1 \mu \mathrm{m}$ fluorescent latex beads (ref. F-13081, Molecular Probes) was added as an internal standard (Calvo-Díaz \& Morán 2006). All cellular variables were
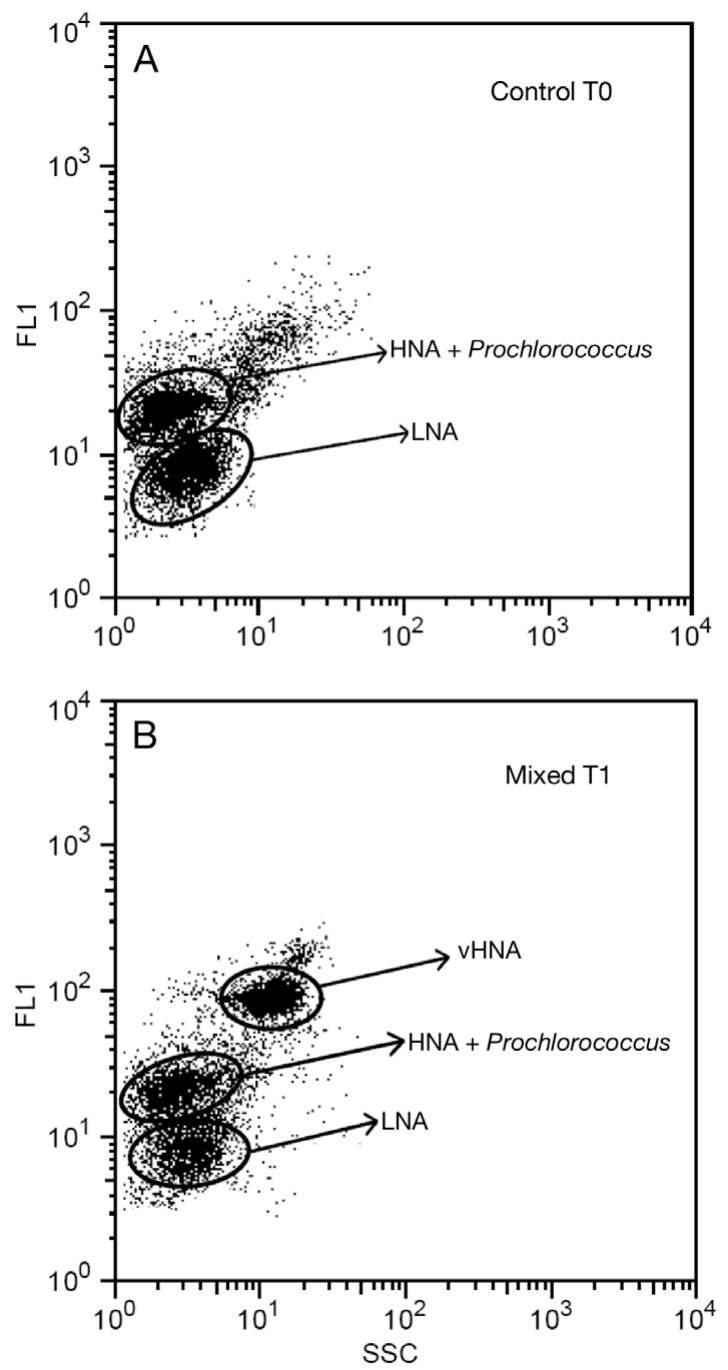

Fig. 2. Scatter plot of green fluorescence versus side scatter (A) at time zero in a control treatment showing low nucleic acid (LNA) and high nucleic acid (HNA) content bacteria, and (B) after $1 \mathrm{~d}$ in a mixed treatment showing LNA, HNA, and very high nucleic acid (vHNA) content bacteria. FL1, green fluorescence; SSC, side scatter

related to fluorescent beads values. An empirical calibration between forward scatter (FSC) and cell diameter specific for this data set, as explained in Calvo-Díaz \& Morán (2006), was used to estimate biovolume (BV) $\left(\mathrm{BV}=0.058 \times \mathrm{FSC}+0.013 ; \mathrm{n}=13, \mathrm{r}^{2}=0.60\right)$. Bacterial biomass was calculated by using a volume-to-carbon conversion factor of $148 \mathrm{fg} \mathrm{C} \mathrm{Cm}^{-3}$ (Gundersen et al. 2002).

Statistical analysis. A repeated-measures ANOVA (RMANOVA) was conducted to assess time (withinsubject factor), treatment (between-subject factor, nutrient additions) and experiment (between-subject factor, sampling location) effects. All data fitted a normal distribution; however, even after log or arcsine data transformation, the homogeneity of covariance matri- 
ces failed for some data sets. For the latter case we applied the Huynh-Feldt adjustment to correct p-values (Scheiner \& Gurevitch 1993). Multiple comparisons (Bonferroni test) with the estimated marginal means were used to interpret interactions between factors.

\section{RESULTS}

\section{Initial environmental and biological conditions}

A summary of environmental and biological conditions at the start of each experiment is given in Table 1. Nitrate and ammonium concentration did not vary along the transect. By contrast, phosphate concentration was higher in the southern than in the northern stations (Table 1). Chl a concentration ranged only from $0.11 \mu \mathrm{g} \mathrm{l}^{-1}$ at the centre of the Southern Atlantic Subtropical Gyre $\left(12^{\circ} \mathrm{S}\right)$ to $0.24 \mu \mathrm{g} \mathrm{l}^{-1}$ at the equatorial Atlantic $\left(3^{\circ} \mathrm{N}\right)$, whereas primary production varied ca. 1 order of magnitude, from very low rates measured at the Northern and Southern Atlantic Subtropical Gyres $\left(26^{\circ} \mathrm{N}\right.$ and $\left.12^{\circ} \mathrm{S}\right)$ to the highest production in the southernmost station $\left(29^{\circ} \mathrm{S}\right)$ (Table 1$)$. Bacterial production, as estimated from rates of leucine incorporation into proteins, was lowest at $26^{\circ} \mathrm{N}$. Microbial respiration, as estimated from rates of in vivo ETS activity, varied by 2 orders of magnitude, with an extremely low rate in the centre of the northern subtropical gyre $\left(26^{\circ} \mathrm{N}\right)$ and highest rates at the equator (Table 1$)$

\section{Initial bacterial community composition}

The initial composition of the bacterial community differed markedly between experiments (Fig. 3). From 45 to $71 \%$ of the total DAPI-stained cells were detected with the mixture of $3 \mathrm{HRP}$-probes covering the domain Bacteria (Fig. 3A). On average, $44 \%$ of the detected bacteria were identified with the set of 4 probes used in the present study to target the SAR11 cluster, the
Roseobacter spp. group, the Bacteroidetes group and the Gammaproteobacteria subclass. On average, Prochlorococcus spp. accounted for $46 \%$ of the detected bacteria (data not shown), thus leaving only $10 \%$ of detected bacteria as non-identified. The most abundant group among these 4 shifted from north to south.
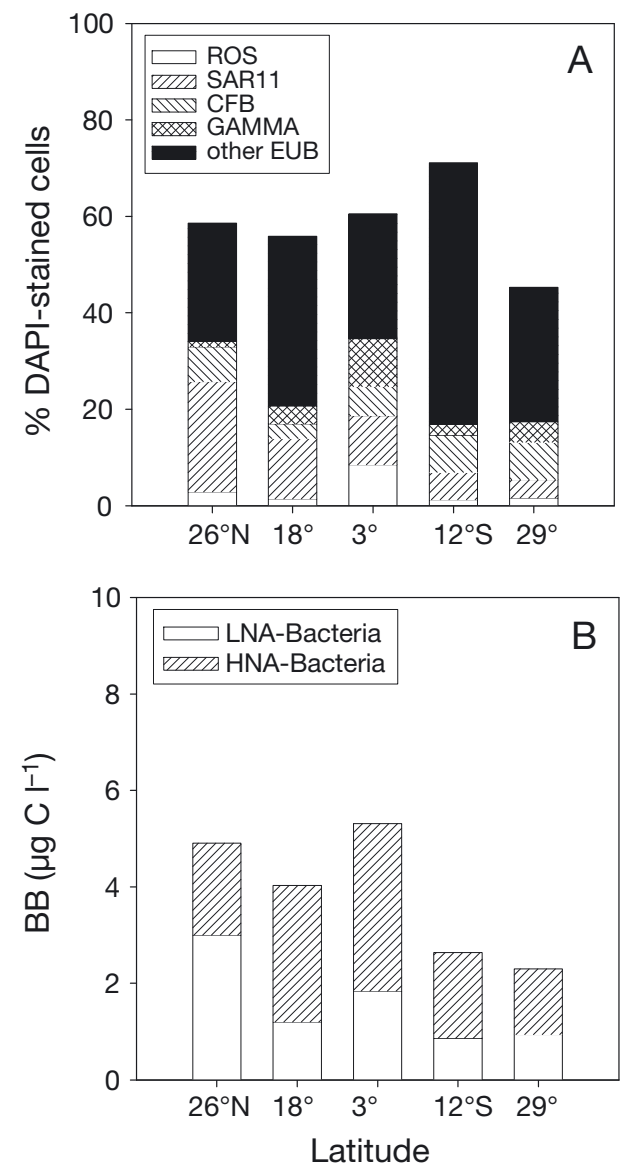

Fig. 3. Initial bacterial community composition at the sampling stations. (A) Relative abundance of major phylogenetic groups expressed as percentage of DAPI-stained cells. ROS, Roseobacter spp.; CFB, Bacteroidetes; GAMMA, Gammaproteobacteria; EUB, Eub338-positive cells. (B) Biomass of low

(LNA) and high (HNA) nucleic acid content bacteria

Table 1. Summary of initial conditions for each experiment. Sampling depth was $10 \mathrm{~m}$ except for Expt 4 (15 m). Nutricline depth was estimated as the first depth were nitrate concentration is $>0.5 \mu \mathrm{M}$. PP, primary production; BP, bacterial production; Leu, leucine; ETS, in vivo electron transport system activity; INTF, iodonitro-tetrazolium formazan

\begin{tabular}{|c|c|c|c|c|c|c|c|c|c|c|}
\hline Expt & $\begin{array}{l}\text { Geographic } \\
\text { coordinates }\end{array}$ & $\begin{array}{l}\text { Temp. } \\
\left({ }^{\circ} \mathrm{C}\right)\end{array}$ & Salinity & $\begin{array}{l}\text { Nitrate } \\
\text { (nM) }\end{array}$ & $\underset{(\mathrm{nM})}{\text { Ammonium }}$ & $\begin{array}{l}\text { Phosphate } \\
\text { (nM) }\end{array}$ & $\begin{array}{c}\mathrm{Chl} \mathrm{a} \\
\left(\mu \mathrm{g} \mathrm{l}^{-1}\right)\end{array}$ & 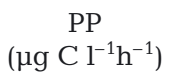 & $\begin{array}{c}\text { BP } \\
\left(\mathrm{pM} \mathrm{Leu} \mathrm{h}^{-1}\right)\end{array}$ & $\begin{array}{c}\text { ETS } \\
\left(\mu \mathrm{M} \text { INTF }^{-1}\right)\end{array}$ \\
\hline 1 & $26^{\circ} \mathrm{N} 34^{\circ} \mathrm{W}$ & 24.6 & 37.57 & $116^{\mathrm{a}}$ & $17^{\mathrm{a}}$ & $25^{\mathrm{a}}$ & 0.155 & 0.018 & 4.1 & 0.002 \\
\hline 2 & $18^{\circ} \mathrm{N} 29^{\circ} \mathrm{W}$ & 25.8 & 36.73 & 116 & 17 & 40 & 0.231 & 0.091 & 29.9 & 0.014 \\
\hline 3 & $3^{\circ} \mathrm{N} 29^{\circ} \mathrm{W}$ & 27.9 & 35.28 & 117 & 12 & $37^{\mathrm{a}}$ & 0.237 & 0.091 & 32.9 & 0.046 \\
\hline 4 & $12^{\circ} \mathrm{S} 29^{\circ} \mathrm{W}$ & 25.6 & 36.94 & 124 & 17 & 75 & 0.110 & 0.025 & 15.9 & 0.018 \\
\hline 5 & $29^{\circ} \mathrm{S} 29^{\circ} \mathrm{W}$ & 22.0 & 35.85 & 113 & $17^{\mathrm{a}}$ & 80 & 0.158 & 0.120 & 13.9 & 0.034 \\
\hline
\end{tabular}


In the northern part of the transect, SAR11 was the dominant detected group, accounting for 39 and $22 \%$ of total detected bacteria at 26 and $18^{\circ} \mathrm{N}$, respectively. This cluster accounted for only ca. $8 \%$ of total bacterial abundance in the southern hemisphere. The dominant group at the southern stations was Bacteroidetes, contributing 10 and $17 \%$ to the total bacterial community at $12^{\circ}$ and $29^{\circ} \mathrm{S}$, respectively. The bacterial community close to the equator was co-dominated by SAR11 (17\%), Roseobacter spp. (14\%) and Gammaproteobacteria $(16 \%)$, with Bacteroidetes also contributing significantly $(10 \%)$.

The flow-cytometry analyses allowed the distinction of 3 bacterial groups based on their nucleic acid staining and scatter signals: LNA, HNA and vHNA bacteria (Fig. 2). There were differences in the relative contribution of HNA and LNA bacteria along the transect (Fig. 3B), whereas the abundance vHNA bacteria was close to the detection limit. The biomass of bacteria was lowest in the southern hemisphere and highest close to the equator. The contribution of the HNA bacteria was also considerably lower at $26^{\circ} \mathrm{N}(39 \%)$ than at the rest of the stations (60 to $70 \%$ ).

\section{Response of cytometric groups to nutrient additions}

The biomass of LNA bacteria barely responded to the various nutrient additions, following the same temporal trend as that in the control (Fig. 4). Similar temporal trends were observed for the HNA bacteria, although the abundance of this group slightly decreased in some nutrient-addition treatments in the northern hemisphere.

The most prominent responses to nutrient additions corresponded to the vHNA bacteria. Whereas the biomass yielded by vHNA bacteria was overall small in the control and after inorganic nutrient addition, they accounted for a considerable fraction of the total bacterial standing stock when organic nutrients were
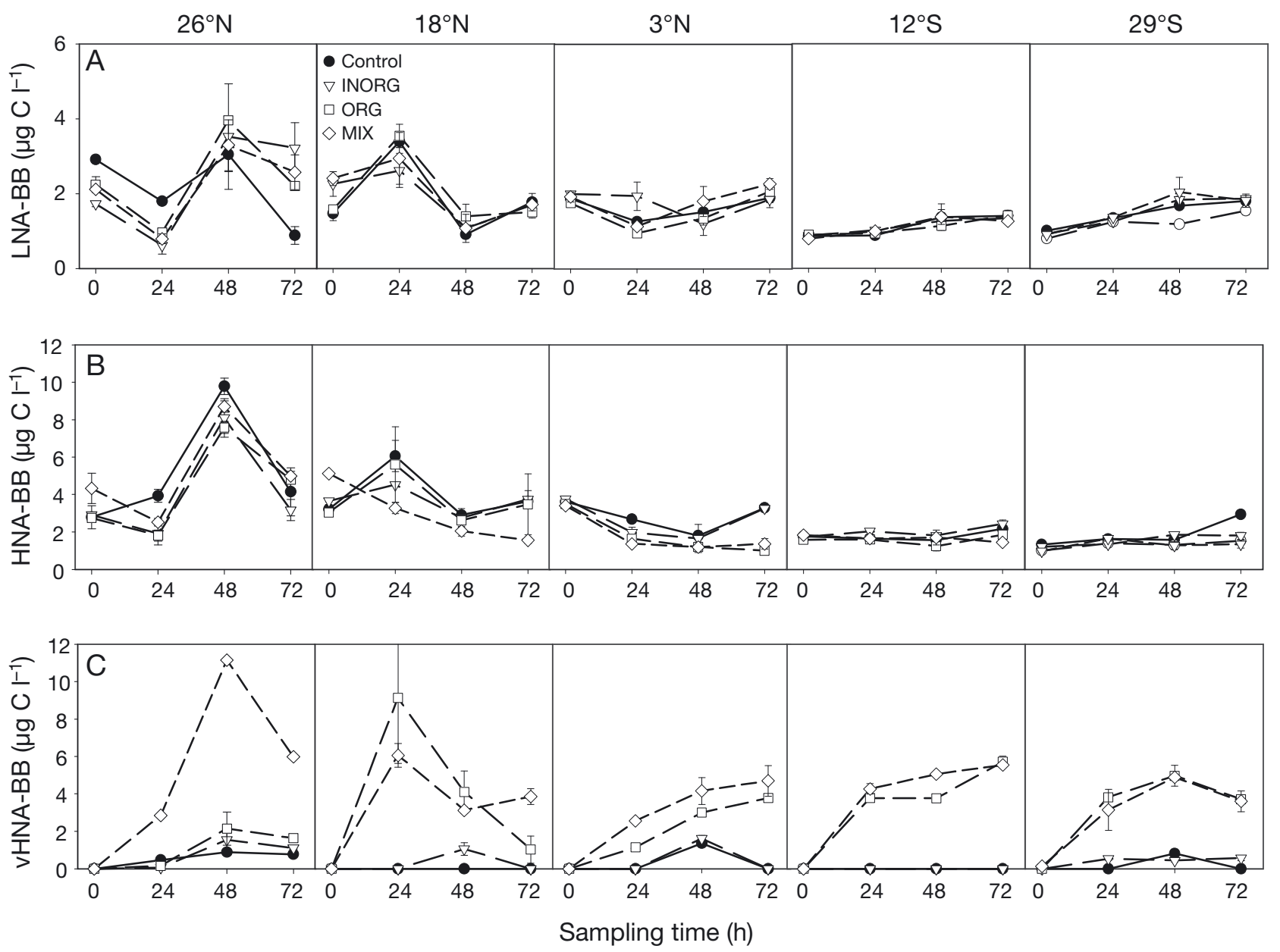

Fig. 4. Time course of the mean (A) low (LNA), (B) high (HNA) and (C) very high (vHNA) nucleic acid content bacterial biomass (BB) in the 5 experiments. INORG, inorganic addition; ORG, organic addition; MIX, mixed addition. Error bars represent SE from 2 replicates 
added, except at $26^{\circ} \mathrm{N}$, where this group developed only when both organic and inorganic nutrients were added (mixed treatment). Except in the $26^{\circ} \mathrm{N}$ experiment, these bacteria closely followed the same temporal pattern and reached similar maximum biomass levels in organic and mixed treatments. The biomass of each bacterial group during the experiments was averaged in order to calculate the percentage of biomass produced after each nutrient amendment relative to the control (Fig. 5). Both LNA and HNA showed little changes relative to control. The RMANOVA test showed a non-significant effect of treatment (Table 2). By contrast, a high variability in the percentage relative to control was observed for the vHNA group, both between treatments and experiments. The RMANOVA test showed a significant effect of both factors (Table 2).


Fig. 5. Time-averaged (A) low (LNA), (B) high (HNA), and (C) very high (vHNA) nucleic acid content bacterial biomass in microcosms amended with inorganic, organic and mixed nutrients, expressed as a percentage relative to the values in the control microcosms. Error bars represent SE. Horizontal line in each graph represents $100 \%$ (no change) relative to control
The inorganic addition did not cause a significant change in the vHNA bacterial biomass, whereas both the organic and the mixed treatments highly stimulated the growth of these bacteria (Table 3). There was a significant interaction between the factors treatment and experiment (RMANOVA; Table 2), which means that the response to the treatment greatly differed among experiments. The Bonferroni post hoc test indicated that the organic treatment had a significant effect in all the treatments $(p<0.02)$ except at $26^{\circ} \mathrm{N}$, whereas the mixed treatment had a significant effect $(p<0.001)$ in all the experiments.

\section{Response of major phylogenetic bacterial groups to nutrient additions}

Both the absolute and the relative abundance (percentage of DAPI-stained cells, \%DAPI) of each major phylogenetic group followed the same temporal trends, leading to exactly the same statistical results and conclusions. To facilitate the description of the changes in the composition of the bacterial community we have here presented the relative abundances (Fig. 6; but see Fig. A1 in Appendix 1 for absolute abundances). The percentage of total bacteria detected remained rather stable during the incubations in the control and inorganic treatment, and slightly increased in the organic and mixed treatments, with percentages ranging from 59 to $78 \%$ DAPI at the end of the experiments.

The 4 considered groups showed variable temporal trends in the control treatments (Fig. 6). Roseobacter spp. showed a reduced temporal variability, maintaining a rather stable population throughout the incubation period. Gammaproteobacteria either remained stable $\left(3^{\circ} \mathrm{N}\right.$ and $\left.29^{\circ} \mathrm{S}\right)$, or slightly increased $\left(26^{\circ} \mathrm{N}\right.$, $18^{\circ} \mathrm{N}$ and $\left.12^{\circ} \mathrm{S}\right)$. On the other hand, SAR11 abundance varied considerably at $26^{\circ} \mathrm{N}$ and $3^{\circ} \mathrm{N}$, and showed a clear decreasing trend in 2 of the 5 experiments $\left(26^{\circ} \mathrm{N}\right.$ and $\left.18^{\circ} \mathrm{N}\right)$. Bacteroidetes also showed a clear decreasing trend in 3 out of 5 experiments. The fact that none of the groups showed a consistent decreasing or increasing trend in the control incubations suggest that the impact of manipulation and confinement was rather low, and that changes in population abundances are likely related to biotic interactions between microbial components.

The response of the different groups to the distinct additions greatly varied among experiments, although some general patterns emerge at a glance (Fig. 6). Roseobacter spp. seems to be stimulated by all the 3 treatments, but especially by organic and mixed additions; the abundance of SAR11 and Bacteroidetes tend to decrease, particularly after organic and mixed addi- 
Table 2. Repeated-measures ANOVA with 1 within-subjects factor (Time, sampling day), and 2 between-subjects factors (Expt, experiment; Treat, treatment). LNA, HNA and vHNA: abundance of low, high and very high nucleic acid content bacteria, respectively. \%ROS, \%SAR11, \%CFB and \%GAM: relative abundance of Roseobacter spp., SAR11, Bacteroidetes and Gammaproteobacteria, respectively. For each pair factor-variable the significance (upper value) and the partial $\eta^{2}$ (lower value, italics) is given. Partial $\eta^{2}$ is an estimate of the proportion of explained variance. ns, not significant

\begin{tabular}{|c|c|c|c|c|c|c|c|}
\hline Factors & LNA & HNA & vHNA & \%ROS & $\%$ SAR11 & $\% \mathrm{CFB}$ & $\%$ GAM \\
\hline \multicolumn{8}{|c|}{ Within-subjects } \\
\hline \multirow[t]{2}{*}{ Time } & 0.004 & 0.022 & $<0.001$ & $<0.001$ & $<0.001$ & $<0.001$ & $<0.001$ \\
\hline & 0.200 & 0.147 & 0.758 & 0.500 & 0.464 & 0.704 & 0.915 \\
\hline \multirow[t]{2}{*}{ Time $\times$ Expt } & $<0.001$ & $<0.001$ & $<0.001$ & $<0.001$ & $<0.001$ & $<0.001$ & $<0.001$ \\
\hline & 0.863 & 0.766 & 0.574 & 0.450 & 0.609 & 0.469 & 0.681 \\
\hline \multirow{2}{*}{ Time $\times$ Treat } & 0.049 & ns & $<0.001$ & $<0.001$ & 0.003 & 0.011 & $<0.001$ \\
\hline & 0.235 & & 0.697 & 0.378 & 0.327 & 0.286 & 0.812 \\
\hline \multicolumn{8}{|c|}{ Between-subjects } \\
\hline \multirow[t]{2}{*}{ Expt } & $<0.001$ & $<0.001$ & ns & $<0.001$ & $<0.001$ & $<0.001$ & $<0.001$ \\
\hline & 0.914 & 0.904 & & 0.755 & 0.932 & 0.694 & 0.645 \\
\hline \multirow[t]{2}{*}{ Treat } & ns & ns & $<0.001$ & $<0.001$ & $<0.001$ & $<0.001$ & $<0.001$ \\
\hline & & & 0.945 & 0.666 & 0.598 & 0.629 & 0.963 \\
\hline \multirow[t]{2}{*}{ Expt $\times$ Treat } & ns & ns & $<0.001$ & 0.035 & 0.006 & ns & $<0.001$ \\
\hline & & & 0.765 & 0.598 & 0.681 & & 0.852 \\
\hline
\end{tabular}

Table 3. Summary of the global effect of the different additions on the relative abundance of the different bacterial groups (Bonferroni post hoc test): 0, no significant change; - , significant decrease $\mathrm{p}<0.05 ;+$, significant increase $p<0.05 ;+++$, significant increase $p<0.001$. LNA, HNA and vHNA: low, high and very high nucleic acid content bacteria, respectively. ROS, Roseobacter spp.; CFB, Bacteroidetes; GAMMA, Gammaproteobacteria

\begin{tabular}{|lccc|}
\hline Variable & Inorganic & Organic & Mixed \\
\hline LNA & 0 & 0 & 0 \\
HNA & 0 & 0 & 0 \\
vHNA & 0 & +++ & +++ \\
ROS & + & +++ & +++ \\
SAR11 & 0 & - & - \\
CFB & 0 & - & - \\
GAMMA & 0 & +++ & +++ \\
\hline
\end{tabular}

tions; and finally Gammaproteobacteria are considerably stimulated after organic and mixed additions. The relative change in response to nutrient additions greatly varied among experiments (Fig. 7). Statistical analysis showed a significant effect of treatment and experiment on the relative abundance of each of these 4 major bacterial groups (Table 2). The effect of inorganic additions was not significant, except in the case of Roseobacter spp., which showed a significant stimulation (Table 3). On the other hand, the addition of organic and mixed nutrients caused a significant increase in the abundance of both Roseobacter spp. and Gammaproteobacteria and a significant decrease of SAR11 and Bacteroidetes abundance (Table 3).

A significant interaction between experiment and treatment was obtained, except for the group Bacteroidetes (Table 2). In the case of Roseobacter spp. there was a significant effect of the inorganic treatment at $26^{\circ} \mathrm{N}$ (Bonferroni test, $\mathrm{p}=0.002$ ), of the organic treatment at $18^{\circ} \mathrm{N}$ and $3^{\circ} \mathrm{N}$ treatments (Bonferroni test, $\mathrm{p}<0.05$ ) and of the mixed treatment at $3^{\circ} \mathrm{N}$ and $12^{\circ} \mathrm{S}$ (Bonferroni test, $\mathrm{p}<0.05$ ). No significant effects were observed at the southernmost station. SAR11 showed a significant negative response only at $3^{\circ} \mathrm{N}$ and $12^{\circ} \mathrm{S}$ after addition of organic and mixed nutrients (Bonferroni test, p < 0.05). Gammaproteobacteria also showed a wide variability among experiments. At $26^{\circ} \mathrm{N}$ only the mixed addition produced a positive response of this bacterial group (Bonferroni test, $\mathrm{p}<0.001$ ). At $12^{\circ} \mathrm{S}$ and $29^{\circ} \mathrm{S}$, organic and mixed additions equally stimulated the growth of Gammaproteobacteria (Bonferroni test, $\mathrm{p}<0.001$ ). In the rest of the experiments, the organic additions highly stimulated these bacteria (Bonferroni test, $\mathrm{p}<0.003$ ), but the addition of both organic and inorganic nutrients further fuelled their growth (Bonferroni test, $\mathrm{p}<0.001$ ).

\section{Initial conditions, bacterial group responses and bulk bacterial production response}

To find out if the magnitude of response of the distinct bacterial groups was related to initial bacterial community composition and/or nutrient status, we explored the correlations between the magnitude of response of the distinct groups to the different addition treatments (i.e. inorganic, organic or mixed) and indicators of the initial nutrient status, such as phosphate and dissolved inorganic $\mathrm{N}$ (nitrate, nitrite and ammonium) concentration; or indicators of the initial bacterial community composition, such as initial relative 

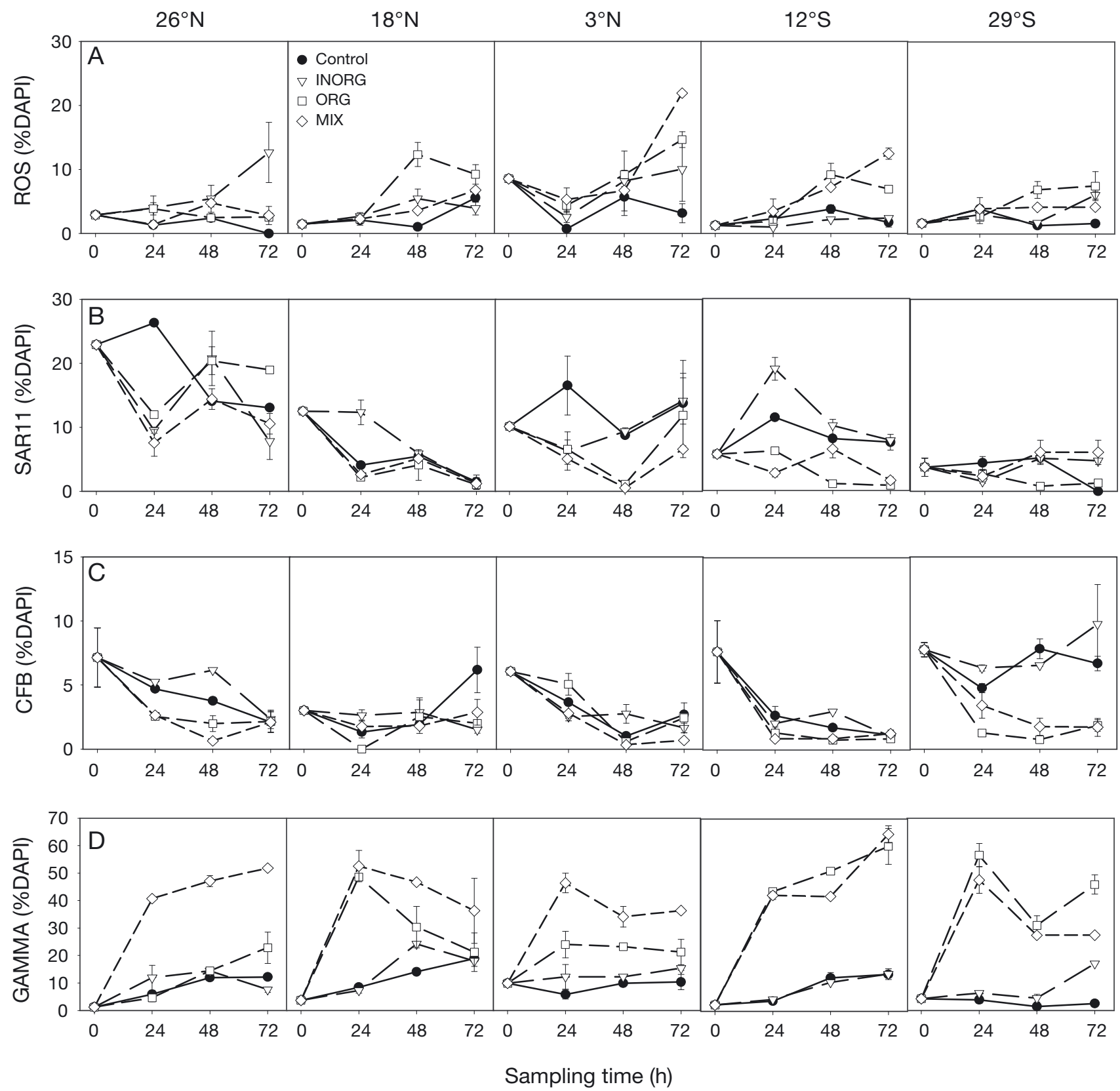

Fig. 6. Time course of the mean relative abundance of (A) Roseobacter spp. (ROS), (B) SAR11, (C) Bacteroidetes (CFB), and (D) Gammaproteobacteria (GAMMA), expressed as percentage of total DAPI-stained cells in the 5 experiments. INORG, inorganic addition; ORG, organic addition; MIX, mixed addition. Error bars represent SE from 2 replicates

abundance of the different phylogenetic and cytometric groups. The initial concentration of phosphate was positively correlated with both the magnitude of response of vHNA bacteria $(\mathrm{r}=0.971, \mathrm{p}<0.01, \mathrm{n}=5)$ and Gammaproteobacteria ( $\mathrm{r}=0.891, \mathrm{p}<0.05, \mathrm{n}=5$ ) to the organic additions (which contain $\mathrm{C}$ and $\mathrm{N}$, but no P). On the other hand, the response of Roseobacter spp. to inorganic additions was negatively correlated to the initial contribution of HNA to total bacterial biomass $(r=-0.939, p<0.05, n=5)$.
We also explored the relationship between the magnitude of response of bacterial groups and the magnitude of response of bulk bacterial production rates (described in Martínez-García et al. 2010), including the 3 different treatments (inorganic, organic and mixed). We found a positive and significant relationship between the response of bacterial production and both Gammaproteobacteria and vHNA bacteria response, which explained 89 and $53 \%$, respectively, of the observed variability (Fig. 8). 

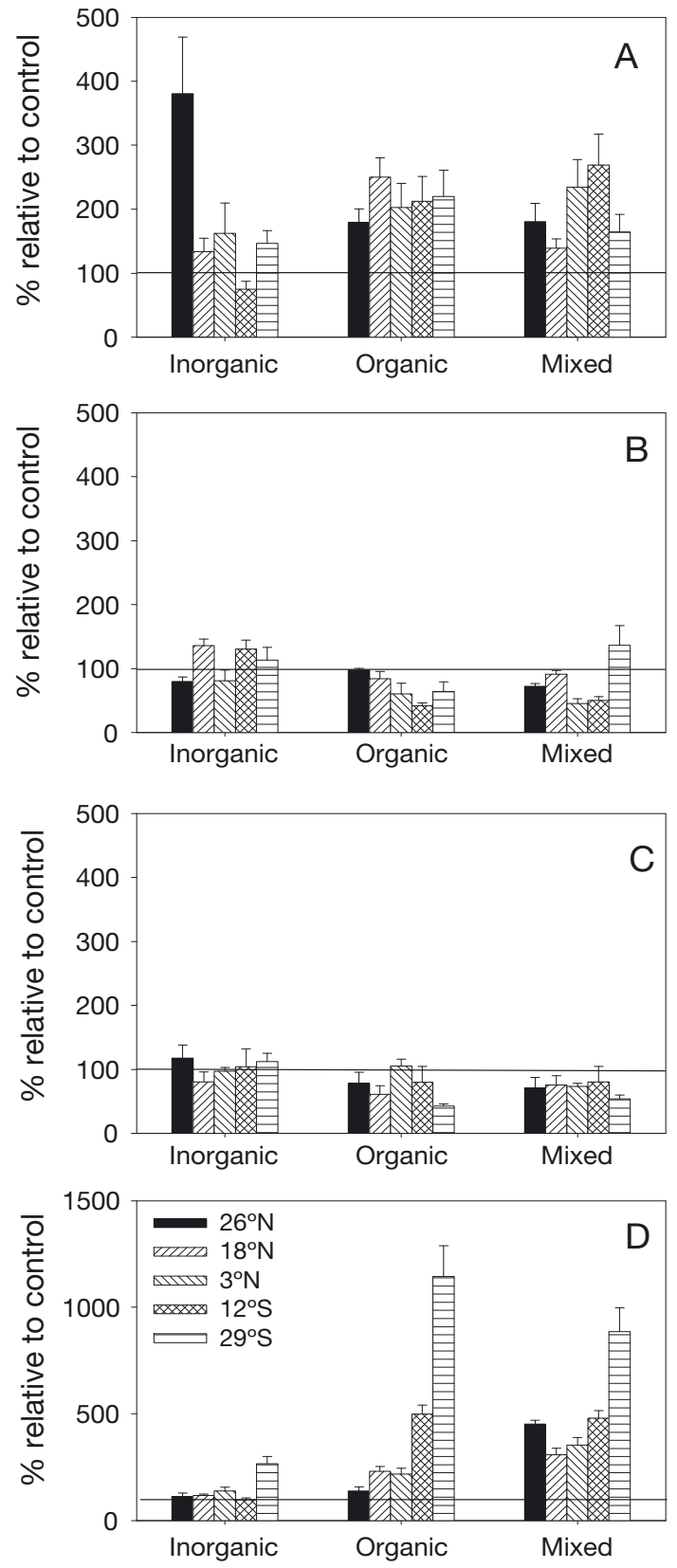

Fig. 7. Time-averaged relative abundance of (A) Roseobacter spp., (B) SAR11, (C) Bacteroidetes, and (D) Gammaproteobacteria, in microcosms amended with inorganic, organic and mixed nutrients, expressed as a percentage relative to the values in the control microcosms. Error bars represent SE. Horizontal line in each graph represents the 100\% (no change) relative to control

\section{DISCUSSION}

An important external input of nutrients in open ocean areas is atmospheric deposition, which is expected to increase as a consequence of human activity (Duce et al. 2008). Given that anthropogenic
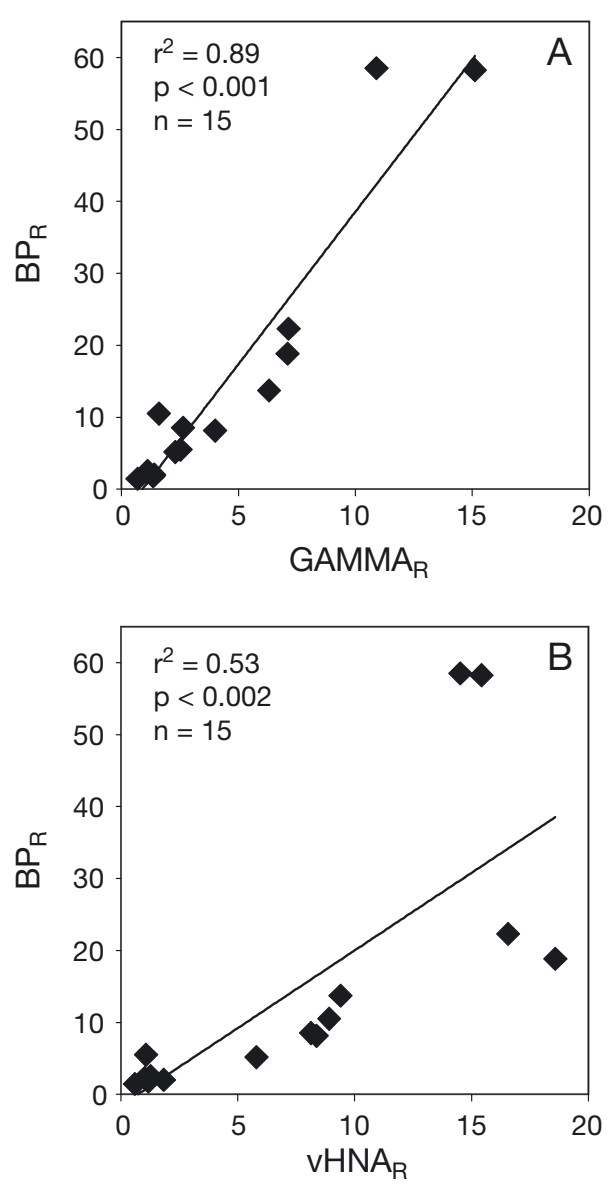

Fig. 8. Relationship between the magnitude of response to nutrient additions of bacterial production $\left(\mathrm{BP}_{\mathrm{R}}\right)$ and the magnitude of response of (A) Gammaproteobacteria $\left(\mathrm{GAMMA}_{\mathrm{R}}\right)$ or

(B) very high nucleic acid content bacteria $\left(\mathrm{vHNA}_{\mathrm{R}}\right)$

organic $\mathrm{N}$ constitutes an important fraction of total $\mathrm{N}$ atmospheric deposition (Cornell et al. 2003, Mace et al. 2003, Jickells 2006), we specifically wanted to address the differential impact of inorganic versus organic nutrients on different bacterial communities sampled along a latitudinal transect in the Atlantic Ocean. The latitudinal differences observed in the initial bacterial composition (Fig. 3) agree with the latitudinal distribution patterns of major bacterial groups reported by Schattenhofer et al. (2009), and are likely related to environmental factors such as the increasing north to south gradient of phosphate concentration (Mather et al. 2008, our Table 1).

\section{Impact of nutrient additions on cytometric bacterial groups}

We detected essentially the same 3 bacterial subgroups as Fuchs et al. (2005) and Fernández et al. 
(2008) on the basis of cytometric characteristics: LNA, HNA and vHNA bacteria (Fig. 2).

Both the LNA and HNA bacteria followed very similar temporal trends in the control and in the 3 different treatments (Figs. 4 \& 5), and overall there was no significant effect of nutrient additions on these 2 bacterial fractions (Table 3). Moreover, the standing stocks of both groups did not show a noticeable net increase/ decrease after $72 \mathrm{~h}$ of incubation. This is consistent with the relative constancy of relative abundance of the LNA bacteria in central Atlantic waters (Mary et al. 2007). The third cytometric group considered here, the vHNA bacteria, is equivalent to the HNA2 group described by Fernández et al. (2008) in open oceanic waters of the NE Atlantic Ocean. In the present study, the abundance of vHNA bacteria conspicuously increased after organic and mixed additions. A stimulation of large elongated bacteria (presumably equivalent to vHNA bacteria) had been previously observed in a coastal embayment by Jacquet et al. (2002). They found that large bacteria developed in mesocosms amended with nitrate, phosphate and glucose, but did not appear either in the control or in mesocosms enriched with only inorganic nutrients or only glucose. The fact that we did not observe a clear response to inorganic additions and that we observed a strong response of these bacteria to organic and mixed additions indicate that their growth is primarily limited by the bioavailability of organic substrates. On the other hand, the response to the organic additions (which provide $\mathrm{C}$ and $\mathrm{N}$ but do not include $\mathrm{P}$ ) was positively correlated to the initial concentration of phosphate. Nishimura et al. (2005) also found a strong positive correlation between the relative abundance of vHNA and the concentration of phosphate in a freshwater lake.

\section{Impact of nutrient additions on the phylogenetic composition of bacterial community}

The response of distinct bacterial groups significantly differed among experiments (Table 2, Fig. 5). Nutrient effects on the bacterial community composition were generally unimportant in the inorganic treatment, in agreement with the result obtained by Carlson et al. (2002), who found that the microbial community composition remained relatively stable after inorganic $\mathrm{N}$ and/or inorganic $\mathrm{P}$ additions. We found 3 general patterns of response: SAR11 and Bacteroidetes were unaffected by inorganic additions and negatively affected by organic additions, Roseobacter spp. responded positively to all types of additions, and Gammaproteobacteria responded positively to organic and mixed treatments. Interestingly, our results agree with the global patterns of distribution of these rele- vant bacterial groups. SAR11 dominates the oligotrophic regions of the ocean (Morris et al. 2002, Alonso-Sáez et al. 2007), and can only be cultured in media containing very low nutrient concentrations (Rappé et al. 2002). Roseobacter spp. are relatively more abundant in coastal eutrophic locations, characterised by high levels of inorganic and organic nutrients (Buchan et al. 2005, Alonso-Gutiérrez et al. 2009). Bacteroidetes are mainly associated with decaying phytoplankton blooms, likely profiting from complex DOC (Pinhassi et al. 2004, Alderkamp et al. 2006, Teira et al. 2008).

Microautoradiography studies combined with FISH or CARD-FISH have shown that the patterns of glucose and amino acids utilisation greatly vary among bacterial groups and even for the same group among different locations (e.g. Del Giorgio \& Gasol 2008). Low ambient levels of substrates appear to represent a competitive advantage for SAR11 bacteria (Alonso \& Pernthaler 2006). Therefore, SAR11 cells would be much less competitive in the uptake of glucose and amino acids than Gammaproteobacteria and Roseobacter spp. at our experimental concentrations $(0.5 \mu \mathrm{M})$. To our knowledge there are no similar previous experiments using natural microbial assemblages where the impact of nutrient additions on SAR11 abundance had been specifically tested. Gammaproteobacteria is a phylogenetically and physiologically diverse group which include some opportunistic bacteria characterised by an extraordinarily high growth potential (Fuhrman \& Hagström 2008). These bacteria have been found to take clear advantage in dilution cultures (Fuchs et al. 2000) and to be highly responsive to manipulation (seawater handling or stirring, confinement, nutrient enrichment) (Eilers et al. 2000, Beardsley et al. 2003. Horñák et al. 2006). Allers et al. (2007) also showed an immediate response of Alteromonadaceae (a Gammaproteobacteria family) in ammonium-amended mesocosms, increasing their relative abundance from 10 to $50 \%$ of DAPI-stained cells in $24 \mathrm{~h}$. In the present study, we did not find prominent bursts of Gammaproteobacteria in the controls or inorganic treatments (Fig. 6), which can be taken as an indicator of reduced confinement/manipulation effects. Interestingly, the magnitude of response of Gammaproteobacteria to organic additions increased from north (1.4-fold increase in relative abundance) to south (15-fold increase in relative abundance) (Fig. 7), which could be related to the increasing inorganic $\mathrm{P}$ availability from north to south (given that the organic addition provides $\mathrm{C}$ and $\mathrm{N}$ but no P) (Table 1). Such gradient in $\mathrm{P}$ availability has been recently reported by Mather et al. (2008). The more P available, the more organic substrates can be used by Gammaproteobacteria. A significant correlation was found between the 
magnitude of response of Gammaproteobacteria to organic additions and the initial phosphate concentration. Davidson et al. (2007) did not observe a response of Gammaproteobacteria to different N additions, likely because they added $\mathrm{P}$ in excess to both controls and treatments.

\section{Links between bacterial community composition and function}

A basic understanding of the links between bacterioplankton community composition and function is crucial for building predictive models of how the pelagic systems will react to global environmental change (Fuhrman \& Steele 2008, Green et al. 2008, Höfle et al. 2008). A wealth of evidence supports a close link between bacterial diversity and both environmental conditions and microbial function (Kirchman 2004, Fuhrman et al. 2006, Alonso-Sáez et al. 2007, Bertilsson et al. 2007, Teira et al. 2008).

It appears that the bacterial community is strongly bottom-up-controlled in oligotrophic areas (Carlson et al. 2002, 2004), where nutrient and C limitation is frequent. It is therefore expected that in such environments, any change in the quantity and/or quality of matter inputs might drive important changes in bacterial diversity and consequently in the cycling of $\mathrm{C}$ through the microbial community. Our results strongly support this hypothesis: changes in the bacterial community composition are closely linked to changes in bacterial activity; in fact, Gammaproteobacteria explained $89 \%$ of the total variability in bulk bacterial activity (Fig. 8). However, we cannot rule out that shifts in bacterial community composition and function are a result of covariation driven by changes in nutrient concentration.

We have shown a strong inorganic P dependence of vHNA bacteria and Gammaproteobacteria. There is a strong positive correlation between Gammaproteobacteria and vHNA bacterial abundance $(\mathrm{r}=0.784, \mathrm{p}<$ $0.001, \mathrm{n}=160$ ), which suggest that the Gammaproteobacteria that responded to the nutrient additions mostly belong to the vHNA category. Microscopic observations corroborated the large size of most Gammaproteobacteria in the organic and mixed treatments. The high $\mathrm{P}$ requirements could be explained by its intrinsically high DNA content. We hypothesise that sharp increases of bacterial production reflect the burst of rapid responders, mostly belonging to Gammaproteobacteria, which have an extraordinary growth potential and can temporarily grow fast enough to overcome predation. Therefore, to some extent, P limitation of bacterial activity could derive from the tight control that $\mathrm{P}$ exerts on bacterial community composi- tion, and consequently, the link found between bacterial community composition and function would be, at least partially, causal. The complex links between environmental factors, bacterial assemblage composition and $\mathrm{C}$ cycling should be further explored in the aim to better predict how the ocean will react to global change.

Acknowledgements. We thank all the people involved in the project TRYNITROP who helped with the preparation and sampling of the experiments, particularly the principal investigator E. Marañón. We also thank the captain and crew on board the RV 'Hespérides'. E. T. was supported by a Juan de la Cierva and a Ramón y Cajal contract from the Spanish Ministerio de Educación y Ciencia (MEC). This research was supported by a MEC grant to E. M. (Project Trynitrop, CTM200405174-C02) and a grant from Xunta de Galicia to E. T. (Project AddEX, PGIDIT06PXIB312222PR).

\section{LITERATURE CITED}

Alderkamp AC, Sintes E, Herndl GJ (2006) Abundance and activity of major groups of prokaryotic plankton in the coastal North Sea during spring and summer. Aquat Microb Ecol 45:237-246

Allers E, Gómez-Consarnau L, Pinhassi J, Gasol JM, Šimek K, Pernthaler J (2007) Response of Alteromonadaceae and Rhodobacteriaceae to glucose and phosphorus manipulations in marine mesocosms. Environ Microbiol 9: $2417-2429$

Alonso C, Pernthaler J (2006) Roseobacter and SAR11 dominate microbial glucose uptake in coastal North Sea waters. Environ Microbiol 8:2022-2030

Alonso-Gutiérrez J, Lekunberri I, Teira E, Gasol JM and others (2009) Pronounced seasonality in bacterioplankton composition of the coastal upwelling system of 'Ría de Vigo', NW Spain. FEMS Microbiol Ecol 70:493-505

Alonso-Sáez L, Gasol JM (2007) Seasonal variation in the contribution of different bacterial groups to the uptake of LMW-DOM compounds in NW Mediterranean coastal waters. Appl Environ Microbiol 73:3528-3535

>Alonso-Sáez L, Arístegui J, Pinhassi J, Gómez-Consarnau L and others (2007) Bacterial assemblage structure and carbon metabolism along a productivity gradient in the NE Atlantic Ocean. Aquat Microb Ecol 46:43-53

Alonso-Sáez L, Sánchez O, Gasol JM, Balagué V, Pedrós-Alio $C$ (2008) Winter-to-summer changes in composition and single-cell activity of near-surface Arctic prokaryotes. Environ Microbiol 10:2444-2454

Alonso-Sáez L, Unanue M, Latatu A, Azua I, Ayo B, Artolozaga I, Iriberri J (2009) Changes in marine prokaryotic community induced by varying types of dissolved organic matter and subsequent grazing pressure. J Plankton Res 31:1373-1383

Amann RI, Binder BJ, Olson RJ, Chisholm SW, Devereux R, Stahl DA (1990) Combination of 16S ribosomal-RNA-targeted oligonucleotide probes with flow cytometry for analysing mixed microbial populations. Appl Environ Microbiol 56:1919-1925

Baker AR, Kelly SD, Biswas KF, Witt M, Jickells TD (2003) Atmospheric deposition of nutrients to the Atlantic Ocean. Geophys Res Lett 30:2296

Baker AR, Jickells TD, Biswas KF, Weston K, French M (2006) Nutrients in atmospheric aerosol particles along the 
Atlantic Meridional Transect. Deep-Sea Res I 53: 1706-1719

Baker AR, Weston K, Kelly SD, Voss M, Streu P, Cape JN (2007) Dry and wet deposition of nutrients from the tropical Atlantic atmosphere: links to primary productivity and nitrogen fixation. Deep-Sea Res I 54:1704-1720

Beardsley C, Pernthaler J, Wosniok W, Amann R (2003) Are readily culturable bacteria in coastal North Sea waters suppressed by selective grazing mortality? Appl Environ Microbiol 69:2624-2630

Bertilsson S, Eiler A, Nordqvist A, Jørgensen NOG (2007) Links between bacterial production, amino-acid utilization and community composition in productive lakes. ISME J 1:532-544

Buchan A, Gonzalez JM, Moran MA (2005) Overview of the marine Roseobacter lineage. Appl Environ Microbiol 71:5665-5677

Calvo-Díaz A, Morán XAG (2006) Seasonal dynamics of picoplankton in shelf waters of the southern Bay of Biscay. Aquat Microb Ecol 42:159-174

- Carlson CA, Ducklow HW (1996) Growth of bacterioplankton and consumption of dissolved organic carbon in the Sargasso Sea. Aquat Microb Ecol 10:69-85

Carlson CA, Giovannoni SJ, Hansell DA, Goldberg SJ and others (2002) Effect of nutrient amendments on bacterioplankton production, community structure, and DOC utilization in the northwestern Sargasso Sea. Aquat Microb Ecol 30:19-36

Carlson CA, Giovannoni SJ, Hansell DA, Goldberg SJ and others (2004) Interactions among dissolved organic carbon, microbial processes, and community structure in the mesopelagic zone of the northwestern Sargasso Sea. Limnol Oceanogr 49:1073-1083

Church MJ, Hutchins DA, Ducklow HW (2000) Limitation of bacterial growth by dissolved organic matter and iron in the Southern Ocean. Appl Environ Microbiol 66:455-466

Cornell SE, Jickells TD, Cape JN, Rowland AP, Duce RA (2003) Organic nitrogen deposition on land and coastal environments: a review of methods and data. Atmos Environ 37:2173-2191

> Daims H, Bruhl A, Amann R, Schleifer KH, Wagner M (1999) The domain-specific probe EUB338 is insufficient for the detection of all Bacteria: development and evaluation of a more comprehensive probe set. Syst Appl Microbiol 22: 434-444

Davidson K, Gilpin LC, Hart MC, Foilland E and others (2007) The influence of the balance of inorganic and organic nitrogen on the trophic dynamics of microbial food webs. Limnol Oceanogr 52:2147-2163

del Giorgio PA, Gasol JM (2008) Physiological structure and single-cell activity in marine bacterioplankton. In: Kirchman DL (ed) Microbial ecology of the oceans, 2nd edn. Wiley-Liss, Hoboken, NJ, p 243-298

> Duce RA, LaRoche J, Altieri K, Arrigo KR and others (2008) Impacts of atmospheric anthropogenic nitrogen on the open ocean. Science 320:893-897

Eilers H, Pernthaler J, Amann R (2000) Succession of pelagic marine bacteria during enrichment: a close look on cultivationinduced shifts. Appl Environ Microbiol 66:4634-4640

Eilers H, Pernthaler J, Peplies J, Glöckner FO, Gerdts G, Amann R (2001) Isolation of novel pelagic bacteria from the German Bight and their seasonal contributions to surface picoplankton. Appl Environ Microbiol 67:5134-5142

Fernández C, Thyssen M, Denis M (2008) Microbial community structure along $18^{\circ} \mathrm{W}\left(39^{\circ} \mathrm{N}-44.5^{\circ} \mathrm{N}\right)$ in the $\mathrm{NE}$ Atlantic in late summer 2001 (POMME programme). J Mar Syst 71:46-62

Frette L, Johnsen K, Jorgensen NOG, Nybroe O, Kroer N
(2004) Functional characteristics of culturable bacterioplankton from marine and estuarine environments. Int Microbiol 7:219-227

Fuchs BM, Zubkov MV, Sahm K, Burkill PH, Amann R (2000) Changes in community composition during dilution cultures of marine bacterioplankton as assessed by flow cytometry and molecular biological techniques. Environ Microbiol 2:191-201

Fuchs BM, Woebken D, Zubkov MV, Burkill P, Amann R (2005) Molecular identification of picoplankton populations in contrasting waters of the Arabian Sea. Aquat Microb Ecol 39:145-157

Fuhrman JA, Hagström A (2008) Bacterial and archaeal community structure and its patterns. In: Kirchman DL (ed) Microbial ecology of the oceans, 2nd edn. Wiley-Liss, Hoboken, NJ, p 45-90

Fuhrman JA, Steele JA (2008) Community structure of marine bacterioplankton: patterns, networks, and relationships to function. Aquat Microb Ecol 53:69-81

> Fuhrman JA, Hewson I, Schwalbach MS, Steele JA, Brown MV, Naeem S (2006) Annually reoccurring bacterial communities are predictable from ocean conditions. Proc Natl Acad Sci USA 103:13104-13109

Galloway JN, Dentener FJ, Capone DG, Boyer EW and others (2004) Nitrogen cycles: past, present, and future. Biogeochemistry 70:153-226

Green JL, Bohannan BJM, Whitaker RJ (2008) Microbial biogeography: from taxonomy to traits. Science 320: 1039-1043

Gundersen K, Heldal M, Norland S, Purdie DA, Knap AH (2002) Elemental C, N, and P cell content of individual bacteria collected at the Bermuda Atlantic Time-Series Study (BATS) site. Limnol Oceanogr 47:1525-1530

$>$ Hasegawa T, Fukuda H, Koike I (2005) Effects of glutamate and glucose on $\mathrm{N}$ cycling and the marine plankton community. Aquat Microb Ecol 41:125-130

Höfle MG, Kirchman DL, Christen R, Brettar I (2008) Molecular diversity of bacterioplankton: link to a predictive biogeochemistry of pelagic ecosystems. Aquat Microb Ecol 53:39-58

Horñák K, Jezbera J, Nedoma J, Gasol JM, Šimek K (2006) Effects of resource availability and bacterivory on leucine incorporation in different groups of freshwater bacterioplankton, assessed using microautoradiography. Aquat Microb Ecol 45:277-289

Jacquet S, Havskum H, Thingstad TF, Vaulot D (2002) Effects of inorganic and organic nutrient addition on a coastal microbial community (Isefjord, Denmark). Mar Ecol Prog Ser 228:3-14

> Jickells T (2006) The role of air-sea exchange in the marine nitrogen cycle. Biogeosciences 3:271-280

> Jurado E, Dachs J, Duarte CM, Simó R (2008) Atmospheric deposition of organic and black carbon to the global oceans. Atmos Environ 42:7931-7939

- Kerouel R, Aminot A (1997) Fluorometric determination of ammonia in sea and estuarine waters by direct segmented flow analysis. Mar Chem 57:265-275

Kirchman DL (1990) Limitation of bacterial growth by dissolved organic matter in the subarctic Pacific. Mar Ecol Prog Ser 62:47-54

Kirchman DL (2004) A primer on dissolved organic material and heterotrophic prokaryotes in the oceans. In: Follows M, Oguz T (eds) The ocean carbon cycle and climate. NATO Science Series. Kluwer Academic Publishers, Dordrecht, p 31-66

> Kirchman DL, Meon B, Cottrell MT, Hutchins DA, Weeks D, Bruland KW (2000) Carbon versus iron limitation of bac- 
terial growth in the California upwelling regime. Limnol Oceanogr 45:1681-1688

Mace KA, Kubilay N, Duce RA (2003) Organic nitrogen in rain and aerosol in the eastern Mediterranean atmosphere: an association with atmospheric dust. J Geophys Res Atmos 108:4320

Malmstrom RR, Cottrell MT, Elifantz H, Kirchman DL (2005) Biomass production and assimilation of dissolved organic matter by SAR11 bacteria in the Northwest Atlantic Ocean. Appl Environ Microbiol 71:2979-2986

Manz W, Amann R, Ludwig W, Wagner M, Schleifer KH (1992) Phylogenetic oligodeoxynucleotide probes for the major subclasses of Proteobacteria-problems and solutions. Syst Appl Microbiol 15:593-600

Manz W, Amann R, Ludwig W, Vancanneyt M, Schleifer KH (1996) Application of a suite of 16S rRNA-specific oligonucleotide probes designed to investigate bacteria of the phylum Cytophaga-Flavobacter-Bacteroides in the natural environment. Microbiology 142:1097-1106

Martínez-García S, Fernández E, Aranguren-Gassis M, Teira E (2009) In vivo electron transport system activity: a method to estimate respiration in natural marine microbial planktonic communities. Limnol Oceanogr Methods 7: 459-469

> Martínez-García S, Fernández E, Calvo-Díaz A, Marañón E, Morán XAG, Teira E (2010) Response of heterotrophic and autotrophic microbial plankton to inorganic and organic inputs along a latitudinal transect in the Atlantic Ocean. Biogeosciences 7:1701-1713

Mary I, Tarran GA, Warwick PE, Terry MJ, Scanlan DJ, Burkill P, Zubkov MV (2007) Light enhanced amino acid uptake by dominant bacterioplankton groups in surface waters of the Atlantic Ocean. FEMS Microbiol Ecol 63:36-45

Mather RL, Reynolds SE, Wolff GA, Williams RG and others (2008) Phosphorus cycling in the North and South Atlantic Ocean subtropical gyres. Nat Geosci 1:439-443

Mills MM, Ridame C, Davey M, La Roche J, Geider RJ (2004) Iron and phosphorus co-limit nitrogen fixation in the eastern tropical North Atlantic. Nature 429:292-294

Mills MM, Moore CM, Langlois R, Milne A and others (2008) Nitrogen and phosphorus co-limitation of bacterial productivity and growth in the oligotrophic subtropical North Atlantic. Limnol Oceanogr 53:824-834

Moore CM, Mills MM, Langlois R, Milne A and others (2008) Relative influence of nitrogen and phosphorus availability on phytoplankton physiology and productivity in the oligotrophic sub-tropical North Atlantic Ocean. Limnol Oceanogr 53:291-305

> Morris RM, Rappé MS, Connon SA, Vergin KL, Slebold WA, Carlson CA, Giovanonni SJ (2002) SAR11 clade dominates ocean surface bacterioplankton communities. Nature 420: 806-810

> Nishimura Y, Kim C, Nagata T (2005) Vertical and seasonal variations of bacterioplankton subgroups with different nucleic acid contents: possible regulation by phosphorus. Appl Environ Microbiol 71:5828-5836

Pernthaler A, Pernthaler J, Amann R (2002) Fluorescence in situ hybridization and catalysed reporter deposition for the identification of marine Bacteria. Appl Environ Microbiol 68:3094-3101

> Pinhassi J, Sala MM, Havskum H, Peters F, Guadayol O, Malits A, Marrasé C (2004) Changes in bacterioplankton composition under different phytoplankton regimens. Appl Environ Microbiol 70:6753-6766

Pinhassi J, Gómez-Consarnau L, Alonso-Sáez L, Sala MM, Vidal M, Pedros-Alio C, Gasol JM (2006) Seasonal changes in bacterioplankton nutrient limitation and their effects on bacterial community composition in the NW Mediterranean Sea. Aquat Microb Ecol 44:241-252

> Pulido-Villena E, Wagener T, Guieu C (2008) Bacterial response to dust pulses in the western Mediterranean: implications for carbon cycling in the oligotrophic ocean. Global Biogeochem Cycles 22:GB1020

Raimbault P, Slawyk G, Coste B, Fry J (1990) Feasibility of using an automated colorimetric procedure for the determination of seawater nitrate in the 0 to $100 \mathrm{~nm}$ range: examples from field and culture. Mar Biol 104:347-351

Rappé MS, Connon SA, Vergin KL, Giovannoni SJ (2002) Cultivation of the ubiquitous SAR11 marine bacterioplankton clade. Nature 418:630-633

Schäfer H, Bernard L, Courties C, Lebaron P and others (2001) Microbial community dynamics in Mediterranean nutrient-enriched seawater mesocosms: changes in the genetic diversity of bacterial populations. FEMS Microbiol Ecol 34:243-253

> Schattenhofer M, Fuchs BM, Amann R, Zubkov M, Tarran GA, Pernthaler J (2009) Latitudinal distribution of prokaryotic picoplankton populations in the Atlantic Ocean. Environ Microbiol 11:2078-2093

Scheiner SM, Gurevitch J (1993) Design and analysis of ecological experiments. Chapman \& Hall, London

Seitzinger SP, Sanders RW (1999) Atmospheric inputs of dissolved organic nitrogen stimulate estuarine bacteria and phytoplankton. Limnol Oceanogr 44:721-730

Sipura J, Haukka K, Helminen H, Lagus A, Suomela J, Sivonen K (2005) Effect of nutrient enrichment on bacterioplankton biomass and community composition in mesocosms in the Archipelago Sea, northern Baltic. J Plankton Res 27:1261-1272

Smith DC, Azam F (1992) A simple, economical method for measuring bacterial protein synthesis rates in seawater using 3H-leucine. Mar Microb Food Webs 6:107-114

- Teira E, Gasol JM, Aranguren-Gassis M, Fernandez A, González J, Lekunberri I, Alvarez-Salgado XA (2008) Linkages between bacterioplankton community composition, heterotrophic carbon cycling and environmental conditions in a highly dynamic coastal ecosystem. Environ Microbiol 10:906-917

Tréguer P, Le Corre P (1975) Manuel d'analyse des sels nutritifs dans l'eau de mer. Utilisation de l'auto analyseur II, Technicon. L.O.C. Université Bretagne Occidentale, Brest

Van Wambeke F, Obernosterer I, Moutin T, Duhamel S, Ulloa O, Claustre H (2008) Heterotrophic bacterial production in the eastern South Pacific: longitudinal trends and coupling with primary production. Biogeosciences 5:157-169 

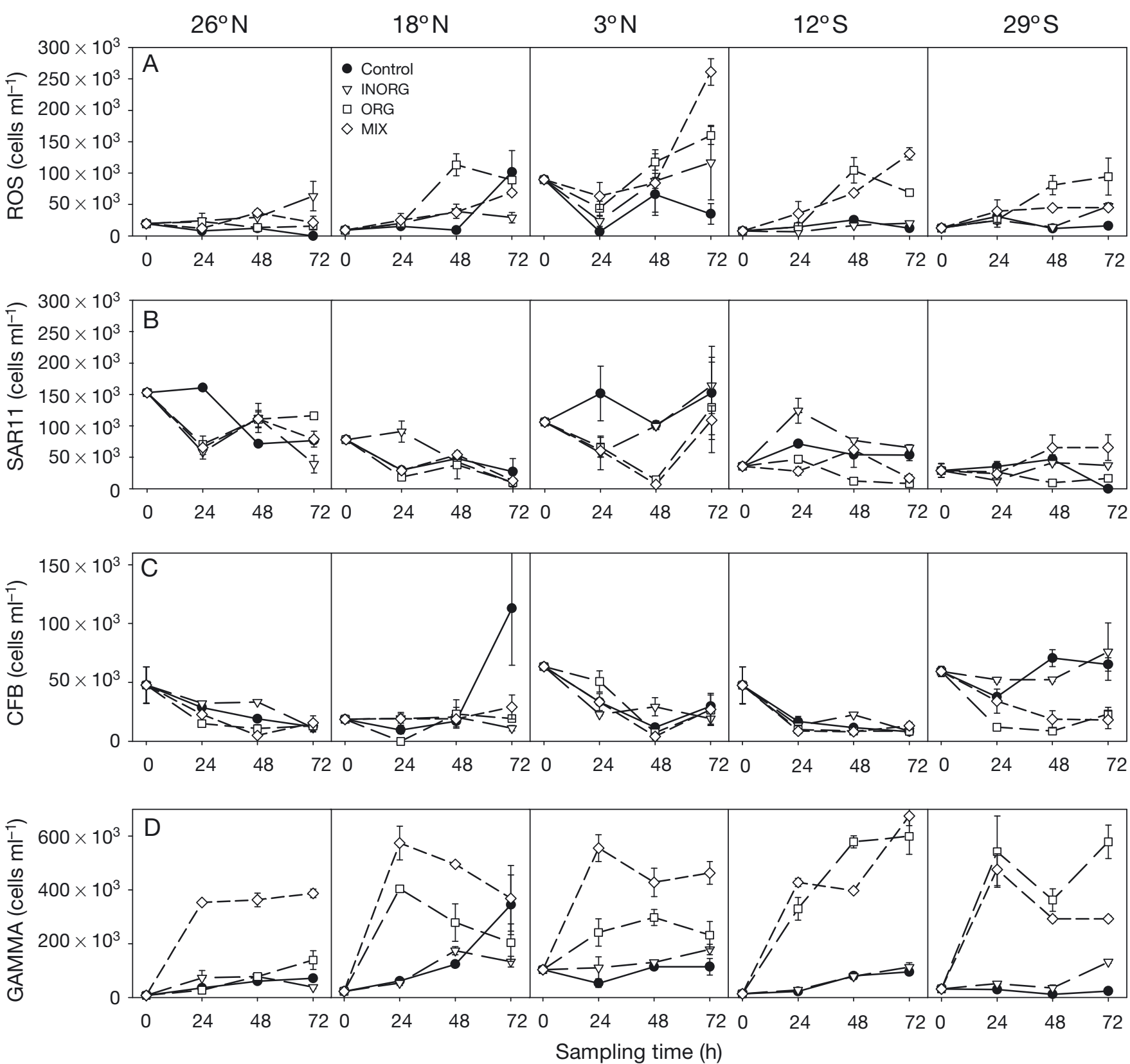

Appendix 1. Fig. A1. Time course of the absolute abundance of (A) Roseobacter spp. (ROS), (B) SAR11, (C) Bacteroidetes (CFB), and (D) Gammaproteobacteria (GAMMA) in the 5 experiments. INORG, inorganic addition; ORG, organic addition; MIX, mixed addition. Error bars represent SE from 2 replicates

Editorial responsibility: Hugh Ducklow, Woods Hole, Massachusetts, USA
Submitted: March 29, 2010; Accepted: June 17, 2010

Proofs received from author(s): July 28, 2010 